\title{
Effect of Full Implementation of Domestic Solar Water Heaters on the Electricity Peak Load in Libya
}

\author{
M. J. R. Abdunnabi ${ }^{1}$, K. Dadesh ${ }^{2}$, O. R. Mrehel ${ }^{2}$ and N. El-shamekh ${ }^{2}$ \\ ${ }^{1}$ Center for Solar Energy Research and Studies, Tajura, Libya \\ ${ }^{2}$ Electrical and Electronic Engineering Dept., Faculty of Engineering, Tripoli University, Libya \\ e-mail:moh_jum@yahoo.com
}

Abstract: Electricity plays an important role in the contemporary life, and it has become indispensible nowadays. Reducing the peak electricity load and increasing the load factor have been considered as one of the main tasks that have to be accomplished by both electricity generation-side and demand-side managements. The residential sector of Libya consumes over $31 \%$ of the total sold electricity, and $29.8 \%$ of that is delivered to the electric water heating load. This is an inefficient way of electricity utilization. Usually, the electricity supplier in Libya used to increase the local generation capacity or import electricity from neighboring countries. Both solutions did not resolve the problem. This work attempts to investigate the effect of replacing electric water heaters in the residential sector of Libya by solar water heaters on reducing the electricity peak load and increasing the load factor. The results show that on average $3 \%$ of the peak load demand can be saved. This is equivalent to $149.5 \mathrm{MW}$ of reduced power. The study also revealed that the annual amount of energy saved is up to $2.55 \mathrm{TWh}$, and the load factor is improved by $2 \%$ (i.e. from $65 \%$ to $67 \%$ ). This saved energy is equivalent to a power plant with a nominal capacity of $448 \mathrm{MW}$ considering a load factor of 0.65 .

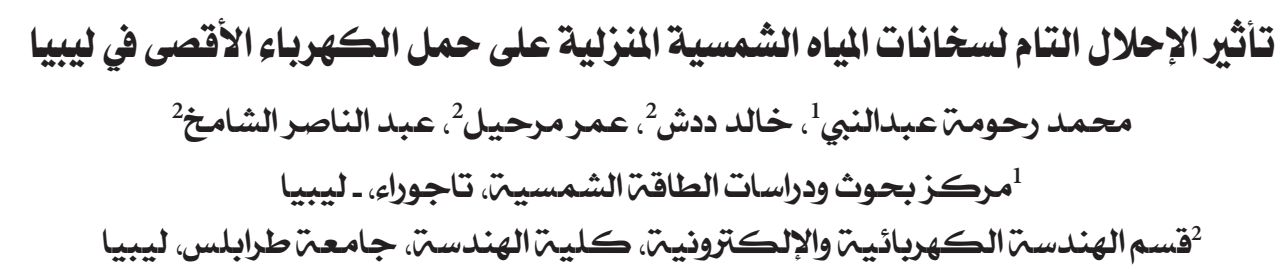

ملـخص: الكهرياء تلعب دورا مهما يِّ الحياه العصريتة، وأصبحت جزءا لا يتجزأ من حياتنا اليوميتة. ويعتبر الخفض من حمل الكهرياء الأقصى والزيادة ِِ معامل الحمل من المهام الرئيست التي يجب إنجازها من خلال جانبي إدارة الطلب والتوليد للكهرياء. يستهلك القطاع

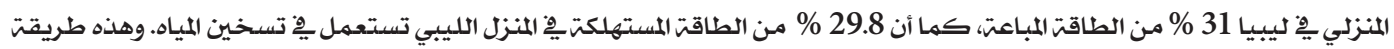




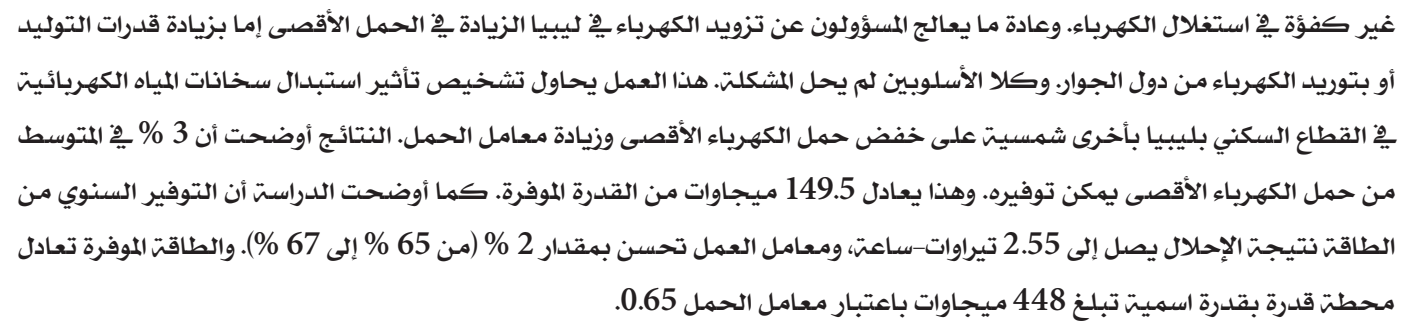

Keywords: solar water heaters, electricity peak load, hot water load pattern, Energy saving,

\section{INTRODUCTION}

Libya witnessed a rapid and significant development in various sectors and economic activities during the last quarter of the previous century. This development led to the growth in electricity demand. It was reported that the energy consumption per dwelling in Libya is over five times the consumption in Morocco. This could be attributed to the fact that electricity price in Morocco is six times electricity price in Libya [1]. The consumption per capita of energy has multiplied more than 13 times from 1970 to 2010, where consumption per capita increased from $338 \mathrm{kWh}$ in 1970 to $4651 \mathrm{kWh}$ in 2010. Therefore, meeting this demand has become a significant problem of concern for its impact on the economy of the country. Thus, it is clear that Libya will face serious challenges as it attempts to meet the rising energy demand. At the same time, it seeks to decrease the dependence on the short-lived and potentially volatile oil and natural gas to reduce negative environmental impacts.

Although Libya possesses high installed capacity per capita compared to other developing countries, Libya has suffered severe electricity shortages. The shortages have become worse in the past few years due to the loss of a part of the generated capacity as a consequence of the unrest in the country, and the ever increasing electricity demand. In the past, this shortage was reduced by importing electricity from neighboring countries. However, this is no longer the case due to the experienced shortage of the electricity in these countries as well. Many solutions have been suggested and implemented to resolve this problem. Quick solutions such as installing new gas turbine power plants and renting diesel generators didn't solve the problem.

From the aforementioned high electricity consumption per capita, it is obvious that it is not an electricity generation problem, but it is a demand management problem. It is believed that implementing energy efficiency and energy saving strategies will alleviate this issue to a great extent. In Libya, almost $100 \%$ of the domestic water heaters are electric, and they consume approximately $9.3 \%$ (3028 GWh) of the total electricity generated in the country in the year 2010 [2]. This is equivalent to a power plant with a capacity of $532 \mathrm{MW}$ considering a load factor of $65 \%$.

Numerous studies have dealt with the demand side management including domestic water heating. Moreau (2010) [3] conducted a study to see the effect of domestic water heaters during peak periods and its impact on the demand for electricity. He suggested a shifted load control strategy to minimize such effect. The study is conducted in the province of 
Quebec, Canada that has a high usage rate of water heaters, of approximately 1.7GW. It is based on an experimentally validated simulation model of water heaters, and the population diversity of hot water load profile. Three scenarios of controlling the number of deactivated water heaters during the peak demand are considered. In scenario 2 the results show that the peak reduction potential is approximately 595 MW at which the pick-up is controlled according to a prioritized random function spread over a range of two hours of the peak period. However, in scenario 0 , controlled reactivation case, the peak demand is $225 \mathrm{MW}$.

To alleviate the effect of the domestic water heating on peak demand and energy consumption, this paper attempts to investigate the influence of replacing electric water heaters with solar water heaters on the Libyan grid. The investigation includes an analysis of peak load in the Libyan electricity supply, hot water load pattern of the residential sector, complete replacement scenario of electrical water heaters with solar ones, and, eventually, estimation of the amount of saved energy, reduced peak power and load factor improvement.

\section{ELECTRICITY SECTOR IN LIBYA}

Libya is a country with a large area and relatively small population scattered all over the place. The state owns General Electric Company of Libya (GECOL) and is solely responsible for the generation and distribution of electricity for the whole country. By law, it has the responsibility of providing electricity to every household in the nation. Libya is a rapidly developing country, and the electrical demand is expected to grow at an annual rate of 6-8 \% for the next 10 years due to the economic development and the improvement of peoples quality of life [4]. Currently, approximately $37 \%$ of the generated electricity is using natural gas, $18 \%$ heavy oil, $34 \%$ light oil, and the rest $11 \%$ is obtained from cogeneration [2]. Apparently, all used energy resources are from fossil fuels, and there is no contribution of new and renewable energy sources.

In Libya, the generated electric energy in 2010 is $32,558 \mathrm{GWh}$, and the total installed power capacity was $8,347 \mathrm{MW}$ with an available power of 6,357 MW [2]. The calculated load factor of this year is $65 \%$. Figure 1 illustrates the average hourly power for the four seasons of the year 2010.

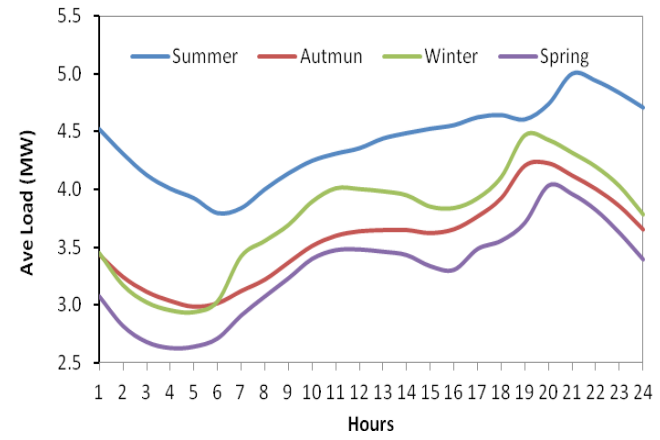

Figure (1). The average load of electricity during the four seasons of the year 2010.

It is clear that the peak power is almost after sunset, and, therefore, using solar energy without storage will not alleviate the peak power demand issue. However, solar water heating technology can store energy for later use, and, therefore, it can be a solution to this dilemma. Figure 2 shows the hourly maximum electricity peak during the year 2010, and reveals that the global maximum is $5,759 \mathrm{MW}$ in August month.

Figure 4 shows the daily maximum electricity load for the year 2010. It is clear that the global peak is in the summer season with $5759 \mathrm{MW}$, and 
the average maximum power during the same season is $5060 \mathrm{MW}$. The second maximum occurs in the winter season with $5360 \mathrm{MW}$ with the daily average maximum power of $4545 \mathrm{MW}$. The lowest maximum season power is in the spring season with $4505 \mathrm{MW}$ and the daily average maximum load of 4111 MW. In the autumn season the maximum peak power is $5523 \mathrm{MW}$, and the daily average maximum peak power during this season is $4333 \mathrm{MW}$. The drop in power between the summer and spring seasons is over $1000 \mathrm{MW}$ in the maximum peak and in the daily average maximum peak. This huge difference could be attributed to the increased demand in buildings to meet the cooling load in the summer season.

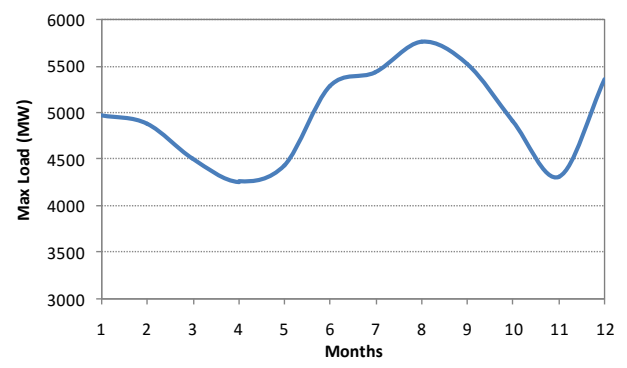

Figure (2). Monthly maximum electricity load for the year 2010

The reported incremental annual average change of the electricity peak load during the past few years is over $8 \%$ as shown in Figure 3. The year 2011 is the year of the revolution in Libya, and the supply of electricity was highly intermittent. Therefore, the years 2011 and beyond are not considered in this study.

Studies made by CADMUS group $[5,6]$ show that the biggest demand at peak hours in the winter season is acquired by the residential sector with $34 \%$.
In the summer season the same sector demands $20 \%$ of the consumed peak energy, which comes the second after the public lighting demand as shown in Figures 5 and 6.

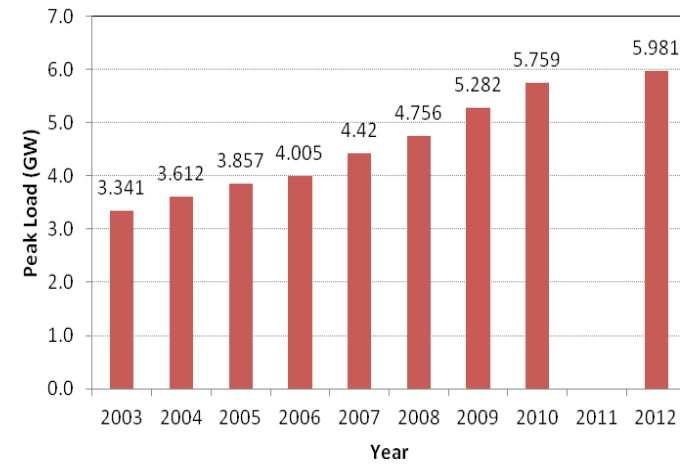

Figure (3). Development of electricity load peak of Libya

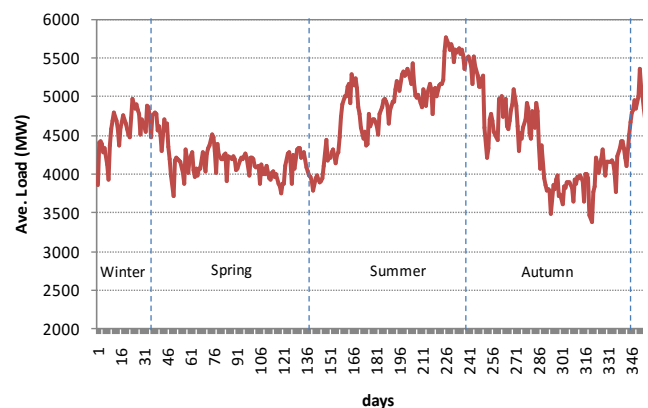

Figure (4). Daily maximum load for the year 2010

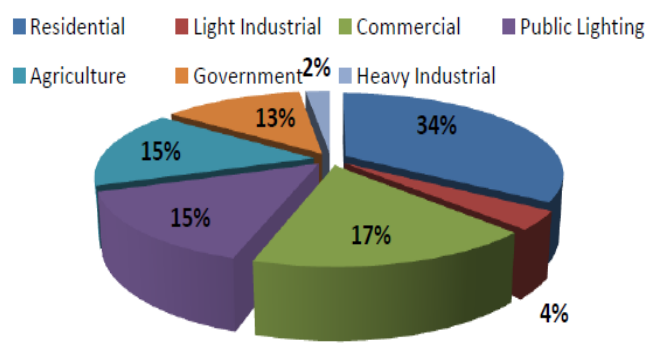

Figure (5). Winter demand at peak hours by sectors

Therefore, implementing energy conservation measures in the residential sector will highly 
alleviate the peak demand issue in the electricity system of Libya. Also the commercial sector composes a greater share of power demand (17\%) than energy consumption (13.06\%). This is expected because these sectors have demand associated more with evening than daytime hours.

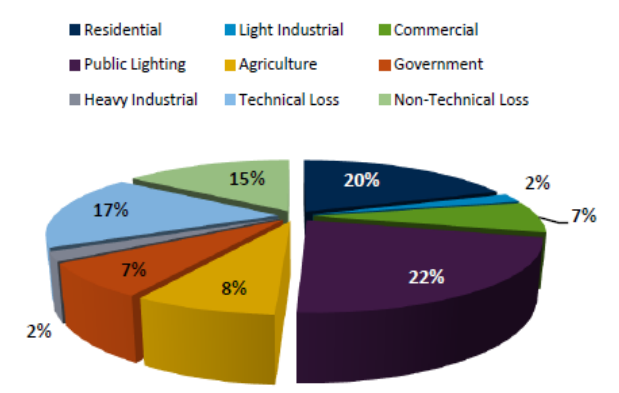

Figure (6). Summer demand at peak hours by sectors

\section{RESIDENTIAL SECTOR}

According to the annual report of General Electric Company of Libya [2], domestic sector consumes $31.18 \%$ of the total electricity sold to different sectors of Libya as shown in Figure 7.

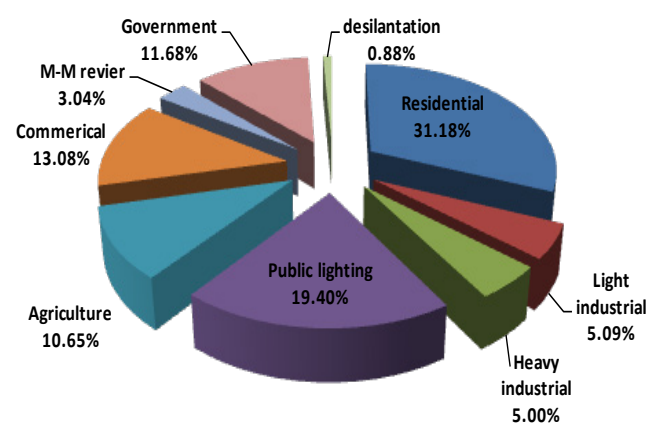

Figure (7). Sectarian distribution of electricity in Libya, 2010

In the meantime, a study conducted by Ekhlat et al. [7] shows that water heating in the domestic sector is the biggest consumer and represents about
$30 \%$ as shown in Figure 8. Thus, around 9.3\% of the national electricity consumption in the country is consumed by water heating for domestic purposes. In the year 2010 the total production of electric energy was about $32,558 \mathrm{GWh}$, and the amount of electricity sold was about 20,602 GWh. Therefore, the annual electricity used for domestic hot water based on generated electricity is around $3028 \mathrm{GWh}$.

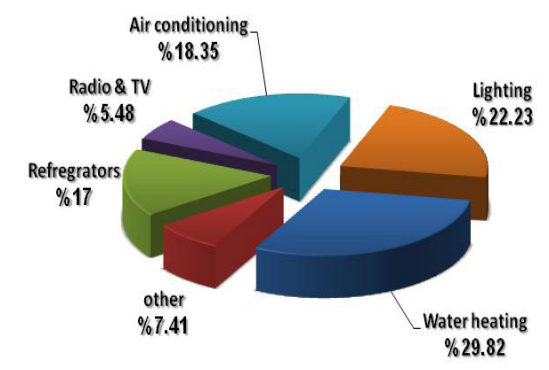

Figure (8). Electricity distribution in the Libyan houses

\section{HOT WATER LOAD IN THE RESIDENTIAL SECTOR}

More than a year of in-situ measurements of five solar water heaters installed in residential buildings are used to predict the average hot-water-load (HWL) pattern and quantity. The measurements were taken every 10 seconds and recorded every 30 minutes for more than a year. In this study, longer periods of measured data are used compared to the previously published data $[18,9]$. The summary of the main results is presented in Table 1. The collected data are analyzed, and the hot water patterns for each season are obtained for the average Libyan family of 6 persons. Figure 9 shows the typical seasonal hot water load pattern for the average Libyan household.

The methodology used to calculate the HWL 
pattern and quantity from the measured data is by unifying the different water quantities from five systems as energy, and the quantity of the water is calculated at withdrawal temperature of $45^{\circ} \mathrm{C}$. The results of all five systems were included in the calculations as shown in Table 1. However, the summer results of the 240 liter system were excluded because the owner of the system declares he was purposely discharging large quantity of hot water daily during the summer season to protect the system from high temperature.
The study reveals that the daily quantity of hot water withdrawn at $45^{\circ} \mathrm{C}$ per person is about 60 liters. The estimated annual amount of energy consumed for water heating per person is about $510 \mathrm{kWh}$. For an average Libyan family of six people, the annual amount of energy consumed is about $3060 \mathrm{kWh}$, which is slightly different from the previously obtained results of $2731 \mathrm{kWh}$ [9]. The study shows also that the average annual solar fraction is $70 \%$.

Table (1). Solar water heaters field study average data

\begin{tabular}{|c|c|c|c|c|c|c|c|}
\hline $\begin{array}{c}\text { Tank } \\
\text { volume } \\
(\mathrm{L})\end{array}$ & $\begin{array}{c}\text { Collector } \\
\text { area }\left(\mathrm{m}^{2}\right)\end{array}$ & $\begin{array}{c}\text { Persons/ } \\
\text { family }\end{array}$ & $\begin{array}{c}\text { Ave } \\
\text { consump. } \\
(\mathrm{Lit})\end{array}$ & $\begin{array}{c}\text { Ave. inlet } \\
\text { Temp } \\
\left({ }^{\circ} \mathrm{C}\right)\end{array}$ & $\begin{array}{c}\text { Ave. outlet } \\
\text { Temp } \\
\left({ }^{\circ} \mathrm{C}\right)\end{array}$ & $\begin{array}{c}\text { Annual } \\
\text { energy } \\
\mathrm{kWh}\end{array}$ & $\begin{array}{c}\text { Solar } \\
\text { Fraction } \\
(\%)\end{array}$ \\
\hline 240 & 3.54 & 6 & 353 & 26.3 & 49.6 & 3450 & 75.2 \\
\hline 280 & 4.4 & 4 & 274 & 24.36 & 47.3 & 2037 & 83.6 \\
\hline 210 & 3.4 & 5 & 158 & 20.55 & 46.4 & 1698 & 57.7 \\
\hline 240 & 3.54 & 4 & 319 & 21.82 & 44.44 & 2925 & 66.1 \\
\hline 170 & 3 & 3 & 131 & 21.91 & 44.2 & 1190 & 58.7 \\
\hline
\end{tabular}

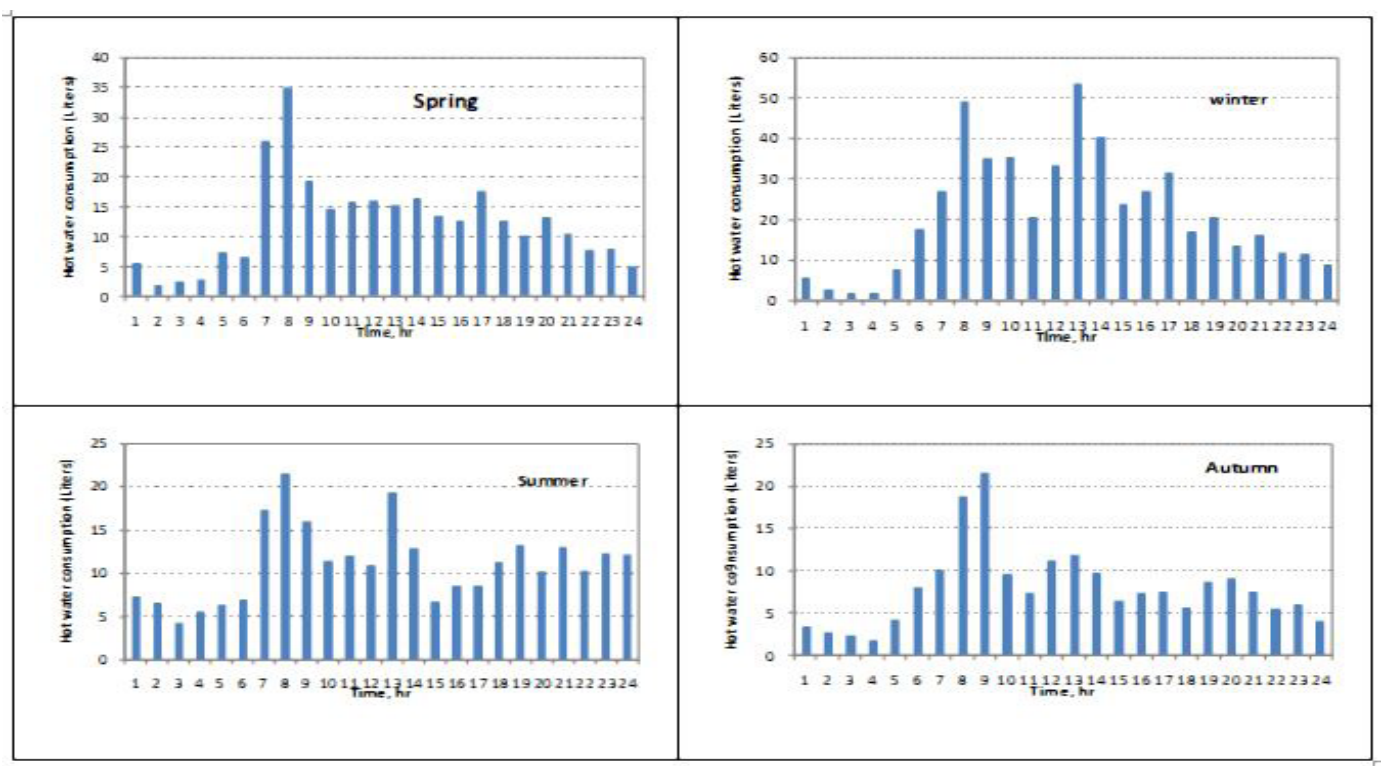

Figure (9). Typical seasonal hot water load pattern of Libyan families 
To estimate the energy used for water heating in residential sector, two approaches are used: The first approach is based on the data obtained from GECOL [2] and General Authority for Information (GAI) [10]. The second approach is based on data collected from SWH field tests. The following sections will go through these two approaches in detail.

\section{First Approach}

This approach will give the possible energy consumed for domestic water heating per family according to data obtained from GECOL and GAI. These data are listed in Table 2.

Table (2). Various data from GECOL and GAI

\begin{tabular}{|l|l|l|l|}
\hline No & \multicolumn{1}{|c|}{ Category } & \multicolumn{1}{|c|}{ Value } & \multicolumn{1}{|c|}{ Remarks } \\
\hline $1-$ & Electric energy sold & $20,602 \mathrm{GWh}$ & GECOL (2010) \\
\hline $2-$ & Electric energy generated & $32,558 \mathrm{GWh}$ & GECOL (2010) \\
\hline $3-$ & $\begin{array}{l}\text { Percentage of water heating in the residential } \\
\text { sector }\end{array}$ & $29.82 \%$ & EKhlat, 2009 \\
\hline $4-$ & $\begin{array}{l}\text { Share of electricity consumption in the } \\
\text { residential sector }\end{array}$ & $31.18 \%$ & GECOL ( Report,2010) \\
\hline $5-$ & $\begin{array}{l}\text { Percentage of electricity used for water } \\
\text { heating in domestic sector }\end{array}$ & $9.3 \%$ & $31.18 \% \times 29.82 \%$ \\
\hline $6-$ & Number of clients & 889,447 & GECOL (Report, 2010) \\
\hline $7-$ & Number of houses, 2010 & 921,642 & GAI, (Report, 2007) \\
\hline
\end{tabular}

From Table 2 we can calculate the maximum possible hot water energy consumption (HWEC) per family based on the generated electricity:

$$
\begin{gathered}
H W E C_{\max }=\frac{\text { Electric EnergyGenerated } \times \% \text { of water heating }}{\text { Number of Clients }} \text {.. } \\
=\frac{32,558,000,000 \times 0.093}{889,447}=3403 \mathrm{kWh}
\end{gathered}
$$

The minimum possible HWEC per family based on electricity sold can be obtained using the same formula:

$H W E C_{\min }=2153 \mathrm{kWh}$

\section{Second approach}

This approach is based on the SWH field test data of HWEC and the data from General Authority for Information (GAI) as given in section 4 .

$H W E C_{\text {measured }}=3060 \mathrm{kWh}$
Fortunately, this measured value lies between the minimum and maximum values obtained using the first approach, which makes this quantity acceptable although the number of measured samples is very small. Therefore, it is chosen to represent the typical value of HWEC for domestic sector of an average Libyan family of six people. This value is representing the useful energy of the hot water and does not represent the energy provided by the electric element in the water tank. The heat loss to the environment is not included.

\section{TRNSYS SIMULATION OF EWH PERFORMANCE}

Commonly used electric water heaters are simulated using TRNSYS simulation program [11] to calculate the heat loss to the environment. It is also used to assess the electric energy required to 
compensate the energy due to heat loss and useful energy consumed (i.e. for typical Libyan house consumption of $3060 \mathrm{kWh}$ /year). Figure 10 shows the implementation of electric water heater in TRNSYS using a simplified electric heater model (Type 60).

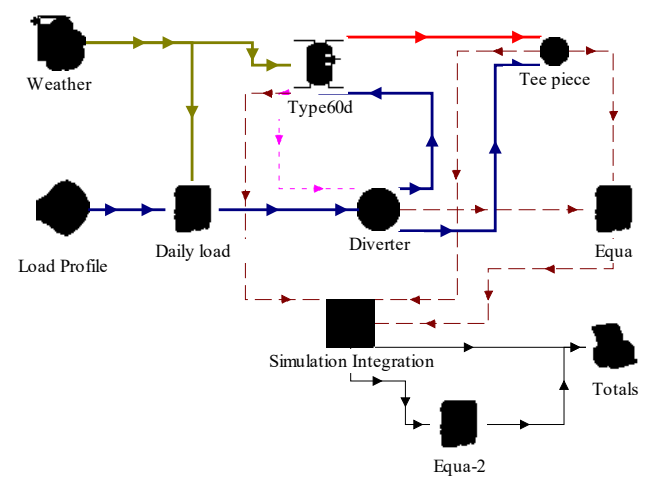

Figure (10). Simulation of EWH in TRNSYS program

The results of a single year simulation of a typical hot water load pattern of a typical Libyan house show that the consumed electric energy is increased by $8 \%$ due to energy loss to the environment as shown in Figure 11. The calculations are made at a set point temperature of $45^{\circ} \mathrm{C}$. The figure also shows the effect of increasing the set point temperature of the electric heater assuming a consumption of the same amount of useful energy (Q_useful). It is clear from the figure that increasing set point temperature from $45^{\circ} \mathrm{C}$ to $60^{\circ} \mathrm{C}$ is accompanied by increase in the energy supplied by $4 \%$ to reach to $12 \%$. Whereas, the heat loss to the environment increased by over $50 \%$. In all calculations of different set point temperatures, the user temperature is maintained at $45^{\circ} \mathrm{C}$.

In this study, it is considered that the common set point temperature is $55{ }^{\circ} \mathrm{C}$. The accompanied heat loss is about $10 \%$. Therefore, the annual energy supplied by the electric heater per family is increased from $3060 \mathrm{kWh}$ to $3364 \mathrm{kWh}$.

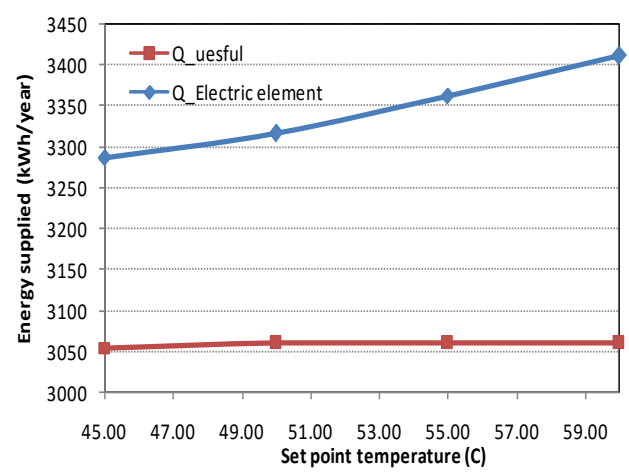

Figure (11). Effect of set point temperature on the energy supply and consumption

\section{THE REPLACEMENT SCENARIO}

The primary results show that the effect of the electricity load of water heating in the residential sector on the electricity peak demand is very small. Therefore, in this study, we will investigate the maximum possible impact of a replacement scenario on the electricity peak demand without going into details of a gradual replacement.

The intended scenario is to replace the electric water heaters of the whole residential buildings by solar water heaters with an average annual solar fraction of $70 \%$. This means that still there is $30 \%$ of the load energy demand that has to be covered by electricity.

\section{RESULTS AND DISCUSSION}

The results obtained for the effect of seasonal hot water consumption on the electric load of the residential sector are shown in Figures 12 to 15. 


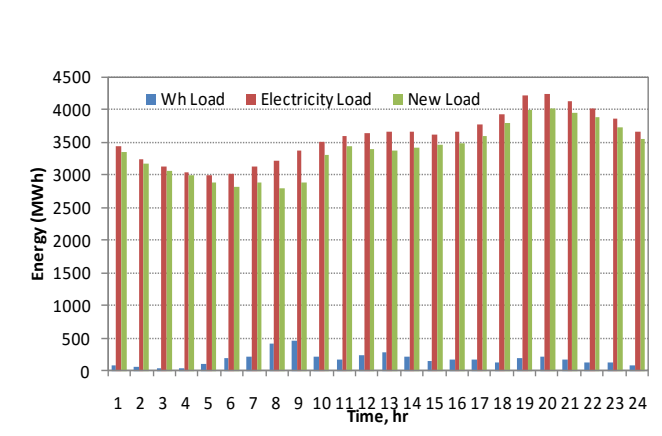

Figure (12). Energy load for autumn season

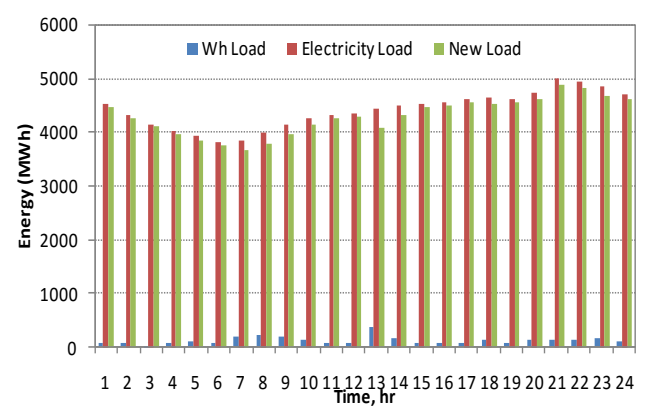

Figure (13). Energy load for summer season

In general, the obvious effect of the replacement scenario is in the winter season, so the peak load drops from $4465 \mathrm{MW}$ to about $4085 \mathrm{MW}$ with maximum saving in the peak load of about $381 \mathrm{MW}$. Thus, the peak load is shifted one hour from 7:00 $\mathrm{pm}$ to 8:00 $\mathrm{pm}$. Unfortunately, the maximum power capacity is needed in the summer season where the lowest savings due to the replacement are achieved. The maximum peak load is nearly $5 \mathrm{GW}$ at 9:00 pm, and the new peak load is $4.85 \mathrm{GW}$ with maximum peak load savings of $149.5 \mathrm{MW}$.

In other mild seasons, autumn and spring, the maximum peak load savings are 237 and $329 \mathrm{MW}$, respectively. The peak times are at 8:00 pm for both seasons, and the new peak is shifted in spring to 9:00 pm, and in autumn it remains at the same time 8:00 pm.
The maximum peak load savings during summer, winter, autumn, and spring are 3\%, 8.5\%, $5.6 \%$, and $8.1 \%$, respectively. The average daily energy savings due to the replacement scenario in the summer, winter, autumn, and spring are 2.96 GWh, 12.8 GWh, 4.88 GWh, and 7.22 GWh, respectively. This is a considerable amount of energy that can be saved due to the suggested replacement scenario. When it comes to the reduction in the maximum capacity power installed due to the replacement scenario, it is only $149.5 \mathrm{MW}$ that can be reduced. The maximum peak load of $5760 \mathrm{MW}$ occurs in the summer (August) at nearly 9:00 pm. Figure 16 shows the electricity load at the day of maximum peak load. The total energy consumption during this day is $122.45 \mathrm{GWh}$.

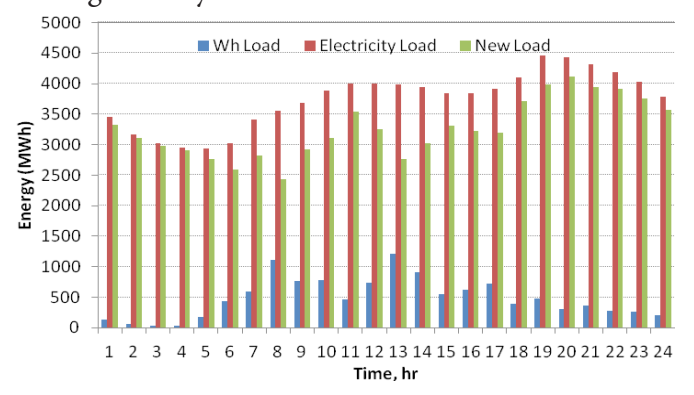

Figure (14). Energy load for winter season

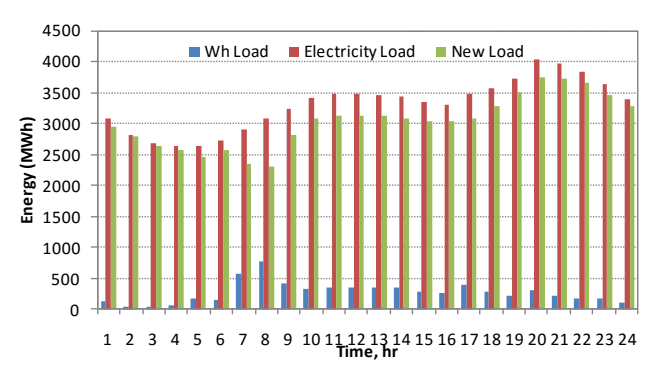

Figure (15). Energy load for spring season

The total annual saved energy using the replacement scenario of EWH with SWH is 2.55 TWh, and the load factor is improved from $65 \%$ 
to $67 \%$. This saved energy is equivalent to a power plant with a capacity of $291 \mathrm{MW}$ considering a load factor of 0.65 , the nominal capacity will be 448 MW. This will be added to the fuel savings and huge environmental benefits due to avoiding burning fossil fuel that releases harmful gases.

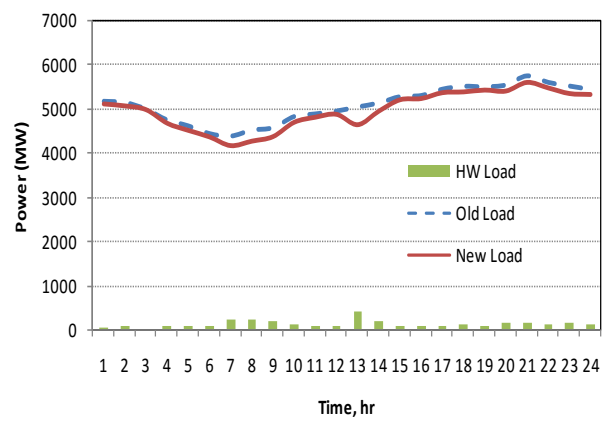

Figure (16). Effect of WH load on summer peak load (15 August)

\section{CONCLUSION}

The Libyan electricity sector suffers from long-term intermittents for many years due to many reasons among which is the poor billing system and high technical and non-technical losses. The total installed capacity is over $8 \mathrm{GW}$ and the available operating capacity in 2010 is about $6.36 \mathrm{GW}$. The variation of the peak load among the four seasons of the year is over $1.5 \mathrm{GW}$ between summer and spring; this variation could be attributed to the energy consumption in buildings. On a daily basis, the maximum variation in the maximum peak load along the year is over $2.3 \mathrm{GW}$ which is a very huge difference and has to be studied. Space heating/ cooling, domestic water heating, and lighting are among the highest energy consumers in buildings.

Water heating for domestic purposes constitutes over $9.3 \%$ of the national electricity consumption, which is equivalent to $3028 \mathrm{GWh}$ in 2010 . The commonly utilized technology for water heating in the residential sector is the electric water heaters, which is the most expensive and pollutant technology. The annual hot water consumption for typical Libyan house is found to be $3060 \mathrm{kWh}$, and the typical seasonal hot water load patterns are also obtained.

The study concluded that replacing electric water heaters with solar water heaters in the residential sector will alleviate the electricity peak by $3 \%(149.5$ MW) and improve the load factor by $2 \%$ (i.e. from $65 \%$ to $67 \%$ ). However, the annual energy savings reach to $2.55 \mathrm{TWh}$, which is equivalent to a power plant with nominal capacity of $448 \mathrm{MW}$ considering a load factor of 0.65 .

\section{REFERENCES}

[1]. Missaoui R., Ben Hassine H., Mourtada A., 2012, Energy efficiency indicators in the Southern and Eastern Mediterranean countries, Regional report, RCREEE.

[2]. GECOL, 2010, General Electric Company Annual Report, 2010.

[3]. Moreau A. 2010. "Control strategy for domestic water heaters during peak periods and its impact on the demand for electricity".

[4]. Planning electric power system studies for Libya: demand forecasting \& generation expansion planning until 2025, 2008, Final report, planning Dept. GPCoEWG and KEPCO, GECOL.

[5]. Khawaja Sami, David Korn, and Josh Keeling, 2010, Report: Winter Load Research for General Electric Company of Libya, The Cadums Group. [6]. Khawaja Sami, David Korn, and Josh Keeling, 
Abdunnabiet al.

口-

2010, Report: Summer Load Research for General Electric Company of Libya, The Cadums Group.

[7]. Ekhlat, M., Azgalah A., and Madhon, M., 2009, Support general electric network of Libya by covering hot water load in the residential sector with solar water heaters, GECoL, internal report.

[8]. Abdunnabi M, 2012. "Optimum Values of Tank Volume to Collector Area Ratios of Thermosyphon Solar Water Heaters for Libyan Families", Journal of Solar Energy and
Sustainable Development, JSESD, No 1, Vol,1, CSERS, 2012

[9]. Abdunnabi, M. and Berwian B, 2005, Economic and environmental benefits of the replacement of Solar water heaters instead of electric heaters in Libya, Scientific Journal of Science, Vol(13), July 2005 (Arabic).

[10]. Statistic report, General Authority for Information (GAI), 2007, Libya.

[11]. Klein, S.A., et al, 2010, TRNSYS 17: a transient simulation program, Solar Energy Laboratory : Madison University of Wisconsin, USA. 